\title{
Enhancing efficiency of biogas collection from industrial organic sludge
}

- Nguyen Thi Thanh Phuong

University of Technology, VNU-HCM

- Nguyen Van Phuoc

Institute for Environment and Resources, VNU-HCM

(Manuscript Received on July 12 ${ }^{\text {nd }}$, 2013, Manuscript Revised October 16 $6^{\text {th }}$, 2013)

\section{ABSTRACT:}

Industrial organic sludge is the concern of society and government levels since this kind of sludge will lead to the pollution of groundwater, surface water, air and the invasion of the food chain, increasing the disease and causing the bad effects on health without collecting and treating thoroughly. For high organic pollutants in sludge, appropriate treatment technology to recover biogas, supply energy for demand of production and living, is one of the current and priority solutions.

Research contents in this study were application of pretreatment by hydrolysis process and anaerobic sequencing batch reactor (ASBR) to enhance biogas recovery. The obtained experimental results by hydrolysis through the alkalization process demonstrated that $C O D$ removal efficiency reached $62 \%$, collected methane gas increased 4.9 times $(360 \mathrm{ml} / \mathrm{L})$ compared to confronting sample (directly digestion, without hydrolyzed phase), at $\mathrm{pH}$ of 12, for 12 hours of hydrolysis time and after 20 digestion days at room temperature (30 $35^{\circ} \mathrm{C}$ ). Research results on anaerobic digestion reactor at organic loading rate of $1,6 \mathrm{~kg} \mathrm{VS} / \mathrm{m}^{3}$. day showed that $\mathrm{COD}$ and $\mathrm{VS}$ removal effiencies can reach 61.59 - 62.24, 52.33 - 54.26\%, respectively for 20 days. The methane yield obtained $0.343-0.402$ $\mathrm{m}^{3} \mathrm{CH}_{4} / \mathrm{kgVS}$ (corresponding to 0.523 $0.628 \mathrm{~m}^{3} \mathrm{CH}_{4} / \mathrm{kg}$ sludge).

Keywords: Anaerobic digestion reactor; Hydrolysis process; Biogas recovery enhancement; Methane yield.

\section{INTRODUCTION}

Currently, the sludge is one of the waste sources may cause environmental pollution and getting increasingly. According to Department of Natural Resources and Environment Ho Chi Minh City (2007), the average daily released sludge was approximately 3,000 tons including 2,000 tons from the dredging of canals and drainage network; 250 tons of sludge from industrial zones; over 500 tons of sludge from septic tank...

However, sludge treatment technologies have not researched and applied appropriately yet in order to recover waste, increase economic efficiency, reduce loading for current landfills and incinerations. In last decades, there were several of methods to enhance sludge anaerobic 
degradability by using pretreatment processes. The treatment may include mechanical, physical, biological, and chemical methods.. Financial feasibility in improving anaerobic digestion methods has been attention due to their application at industrial scale. Liu et al. (2008) carried out sludge hydrolysis by some different methods such as thermo-alkaline, thermo-acid, ultrasonic-alkaline, and ultrasonic-acid. The comparison results showed that alkaline treatment was more effect than other methods. Chulhwan Park et al. (2005) used either thermochemical or biological hydrolysis for waste activated sludge treatment. The research result determined thermochemical hydrolysis was better than biological hydrolysis in a bench-scale operation with the COD removal efficiency, volatile solid (VS) removal efficiency, methane yield and methane biogas content were $88.9 \%$, $77.5 \%, 0.52 \mathrm{~m}^{3} / \mathrm{kg}$ VS and $79.5 \%$, respectively.

Thermo-chemical pretreatment can be employed with different temperature ranges such as ambient temperature, moderate range (60$\left.100^{\circ} \mathrm{C}\right)$, medium temperature range $\left(100-175^{\circ} \mathrm{C}\right)$ or in high temperature range $\left(175-225^{\circ} \mathrm{C}\right)$ (Lin et al., 1997; Hiraoka, 1984; Li and Noike, 1992; Haug, 1983). Besides, it is necessary to add appropriate amounts of alkali agent with the purpose of keeping $\mathrm{pH}$ in the neutral region (Mukherjee and Levine, 1992).

In general, the pretreatment processes affected significantly to sludge treatment results. Therefore, in order to increase the efficiency of anaerobic digestion of industrial sludge and enhance the biogas production, it is necessary to carry out more researches to select appropriate conditions for industrial sludge treatment.

2. BIOREACTOR CONFIGURATION AND EXPERIMENTAL METHODS

\subsection{Sludge Hydrolysis}

Seed sludge and chemical
The seed sludge was taken from the concentrated wastewater treatment plant of Vinh Loc Industrial zone and the primary characteristic was as follows tCOD of 23,784 $\pm 2,527 \mathrm{mg} / \mathrm{l}$; TS of $20,235 \pm 224 \mathrm{mg} / \mathrm{l}$; VSS of $8,744 \pm 351 \mathrm{mg} / \mathrm{l}$, TOC of $2.83 \pm 0.03 ; \mathrm{pH}$ of $6.42 \pm 0.02$.

\section{Reactor operation}

The experiments were carried out at room temperature of $30-34^{\circ} \mathrm{C}$ and seperated into three parts including alkaline hydrolyse, thermal hydrolyse and anaerobic digestion. In which, alkaline hydrolyse using $\mathrm{NaOH}$ was conducted at adjusted $\mathrm{pH}$ of $7,8,9,10,11$ and 12 with controled moisture of $90 \%$. While thermal hydrolyse was carried out at initial $\mathrm{pH}$ of 12 . A wide range of temperatures has been studied at $55,70,100,125,150$ and $170^{\circ} \mathrm{C}$. After reaction times of 30 minutes, the mixture was shaked and sampled then centrifuged at $4000 \mathrm{rpm} / \mathrm{min}$ for 20 minutes before analyzing selected parameters.

Alkaline hydrolysis study was conducted in a batch reactor of 1 liter, which placed on a shaker to stir the mixture of sludge and water. While, thermal hydrolysis study was carried out on the special tube that resistant to heat as well as pressure, besides reaction tube was covered with the lid to prevent evaporation. The basic parameters such as $\mathrm{pH}$, alkalinity, sCOD, TS, VS, VFA were periodical analyzed after 2 hours.

The study of anaerobic digestion was conducted with alkaline hydrolysed sludge with and without adding Aqua Clean/ACF32.

Basically, AquaClean/ACF 32 is a community of microorganisms are cultured in liquid form, are specially selected for use in all industrial wastewater treatment systems. AquaClean/ACF 32 contains a mixture of 12 microorganisms were selected with density 387/450 million bacteria/mL. Therefore, with addition of probiotics, the system was supported groups of high activity microorganisms, digested quickly and efficiently compounds of celllulose; starch; 
proteins, lipids... cause to increase the COD removal efficiency and destroy pathogenic microorganisms. Aqua Clean/ACF32 enhances the biological oxidation of slow to degrade organic compounds significantly improving overall system performance and stability.

VS loading rate was changed from $1,6 \mathrm{gVS} / \mathrm{m}^{3}$.day to $8 \mathrm{gVS} / \mathrm{m}^{3} /$ day, and and a hydraulic retention time (HRT) varying 30, 20, 10, 6 days. Added AquaClean/ACF32 concentration was $10 \mathrm{ppm}$.

At each loading rate, sampling and analyzing main parameters included sCOD, $\mathrm{pH}$, alkalinity, VFA, VS. Particular, methane was measured daily by gas accounted clock.

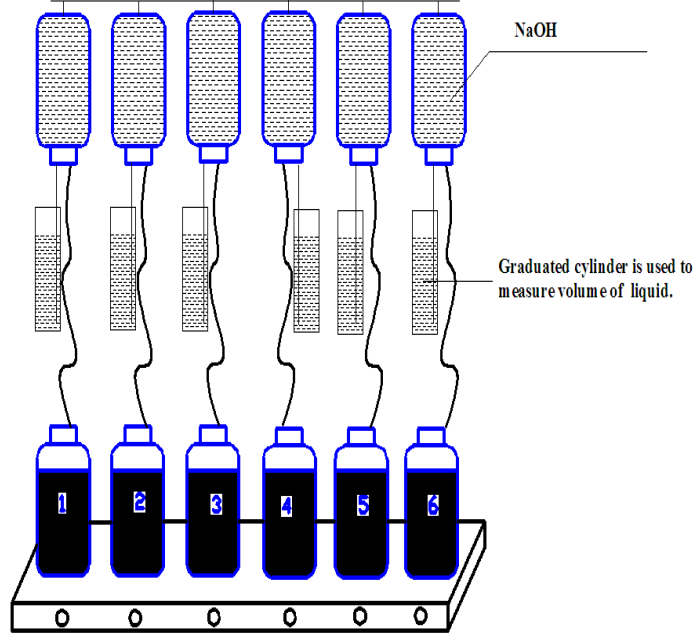

Fig. 1: Anaerobic sequencing batch reactor (ASBR)

\subsection{Analytical method}

Mixture samples were taken every day. $\mathrm{pH}$, alkalinity, COD, VS, TS, VFA were analyzed according to standard method for the examination of water and wastewater (APHA 2005).

\section{RESULTS AND DISCUSSION}

\subsection{Chemical pretreatment by using $\mathrm{NaOH}$}
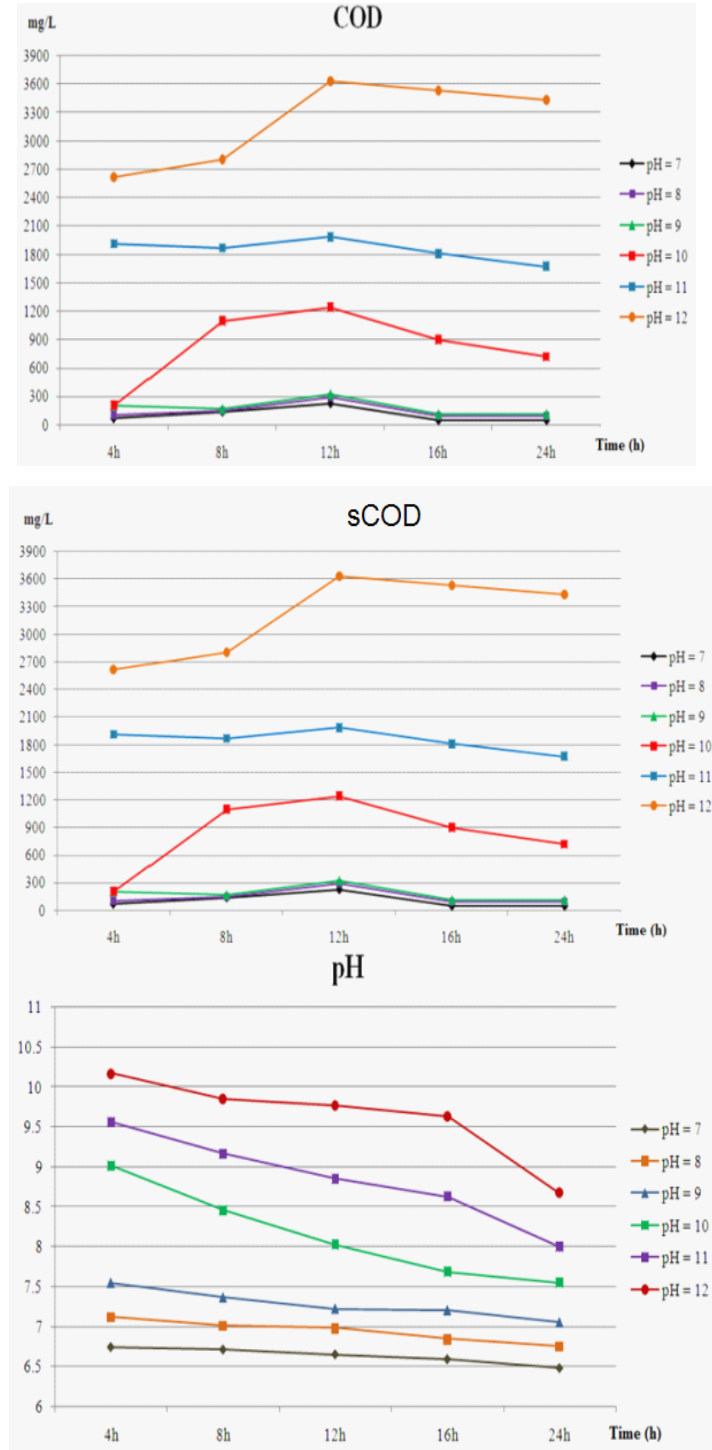

Fig. 2: The variation of $\mathrm{sCOD}$ and $\mathrm{pH}$ at different $\mathrm{pH}$

$\mathrm{pH}$ is an important parameter, affecting the sludge treatment efficiency. The higher the $\mathrm{pH}$ is, the higher sludge hydrolysis ability increases, leading to increase in sCOD. At $\mathrm{pH}$ of 7, 8, 9, sCOD was very low, fluctuated from 50 to 300 $\mathrm{mg} / \mathrm{L}$ after 24 hours operation. sCOD increased slightly as $\mathrm{pH}$ stepped up from 7 to 9 . When $\mathrm{pH}$ changed from 10 to 12 , compared to neutral $\mathrm{pH}$ $(\mathrm{pH}=7)$, sCOD increased dramatically. As a results, sCOD was 3 to 4 times higher at $\mathrm{pH}$ of

\section{Trang 86}


10; 5 to 7 times higher at $\mathrm{pH}$ of 11 and 9 to 12 times higher at $\mathrm{pH}$ of 12 . The final sCOD achieved $12000 \mathrm{mg} / \mathrm{l}, 20000 \mathrm{mg} / \mathrm{l}$ and 36000 $\mathrm{mg} / \mathrm{l}$, respectively.

sCOD was not only affected by $\mathrm{pH}$ but also depended on hydrolysis time. At the first 8 to 12 hours , sCOD increased rapidly with maximum COD concentration of $3600 \mathrm{mg} / \mathrm{l}$ for alkaline hydrolysis at pHof 12 , also in the next 12 hours, sCOD only reduced to $300 \mathrm{mg} / \mathrm{L}$. Obviously, the alkaline hydrolysis can disrupt flocs and cells, release inner organic matters and accelerate sludge hydrolysis (Novelli et al., 1995; Lin et al., 1997)

To sum up, pretreatment period gained optimum efficiency at $\mathrm{pH}$ of 10 to $\mathrm{pH}$ of 12 , and hydrolysis time of 12 hours. $\mathrm{NaOH} 6 \mathrm{~N}$ was considered as an appropriate chemical for $\mathrm{pH}$ adjustment. From the above research results, sludge hydrolysis process was tested again at 3 $\mathrm{pH}$ levels of 10, 11 and 12. Table 1 showed the chemical characterization of sludge as follow.

Table 1: Chemical characterization of primary sludge

\begin{tabular}{|c|c|c|c|c|}
\hline Parameter & Unit & $\mathrm{pH}=10$ & $\mathrm{pH}=11$ & $\mathrm{pH}=12$ \\
\hline tCOD & $\mathrm{mg} / \mathrm{L}$ & $\begin{array}{c}24963 \\
\pm 314\end{array}$ & $\begin{array}{c}25017 \pm \\
338\end{array}$ & $\begin{array}{c}25164 \pm \\
213\end{array}$ \\
\hline sCOD & $\mathrm{mg} / \mathrm{L}$ & $494-898$ & $\begin{array}{c}1387- \\
2156\end{array}$ & $868-3650$ \\
\hline VFA & $\mathrm{meq} / \mathrm{L}$ & 64 & 96 & 118 \\
\hline TDS & $\mathrm{g} / \mathrm{L}$ & 1.665 & 3.687 & 5.463 \\
\hline VDS & $\mathrm{g} / \mathrm{L}$ & 0.888 & 1.375 & 3.008 \\
\hline
\end{tabular}

(Sources: Environmental Technology Laboratory - Institute for Environment and Resources)

Research results showed that VFA after alkalization at $\mathrm{pH}$ of 12 was 1.9 times higher than VFA value after alkalization at $\mathrm{pH}$ of 10 . Datta's research (1991) also included alkali pretreatment process can increase VFA by using $\mathrm{NaOH} 1 \%$.

Advantages of alkalization process are crosslinked destructibility, cellulose hydrolysis, release acid led to increase VFA.

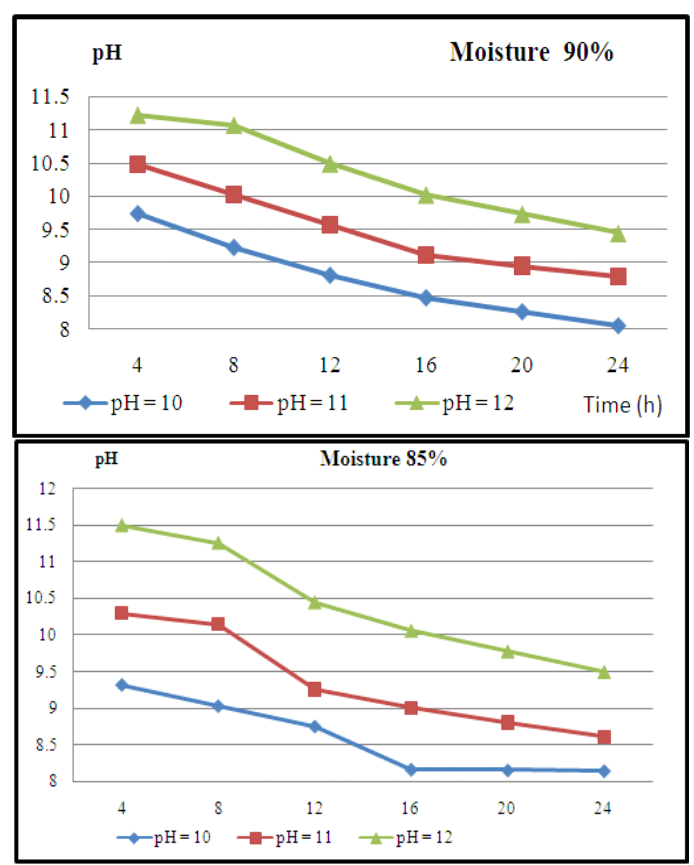

Fig. 3: $\mathrm{pH}$ variation with time at different $\mathrm{pH}$

The $\mathrm{pH}$ curves of the experiments were almost similar to each other, as indicated by the $\mathrm{pH}$ decrease over time. With sludge humidity of $90 \%, \mathrm{pH}$ tends to decrease rapidly in the first 16 minutes and reduce slower in the next 8 hours. The $\mathrm{pH}$ 's reduction rate is greater when the $\mathrm{pH}$ is higher. $\mathrm{pH}$ decreased $2.09-2.25$ unit, $2.38-2.4$ unit; and $2.84-3.19$ unit respectively at $\mathrm{pH}$ of 10, 11 and 12, respectively.

Similarly to $\mathrm{pH}$, VFA also has a significant change with the time. In $4-12$ hours, VFA increased up to the peak then decreased. After the hydrolysis reaction, at $\mathrm{pH}<10$, acidogenic bacteria were provided favorable conditions to develop. This can be explained that lipid, amino acid degradation process convert to formic acid ( $\mathrm{HCOOH})$, acetic acid $\left(\mathrm{CH}_{3} \mathrm{COOH}\right)$, propionic 
acid $\left(\mathrm{CH}_{3} \mathrm{CH}_{2} \mathrm{COOH}\right)$, iso-butylic acid $\left(\left(\mathrm{CH}_{3}\right)_{2} \mathrm{CHCH}_{2} \mathrm{COOH}\right), \mathrm{VFA}$ and bi-products. $\left(\left(\mathrm{CH}_{3}\right)_{2} \mathrm{CHCOOH}\right)$, iso valeric acid

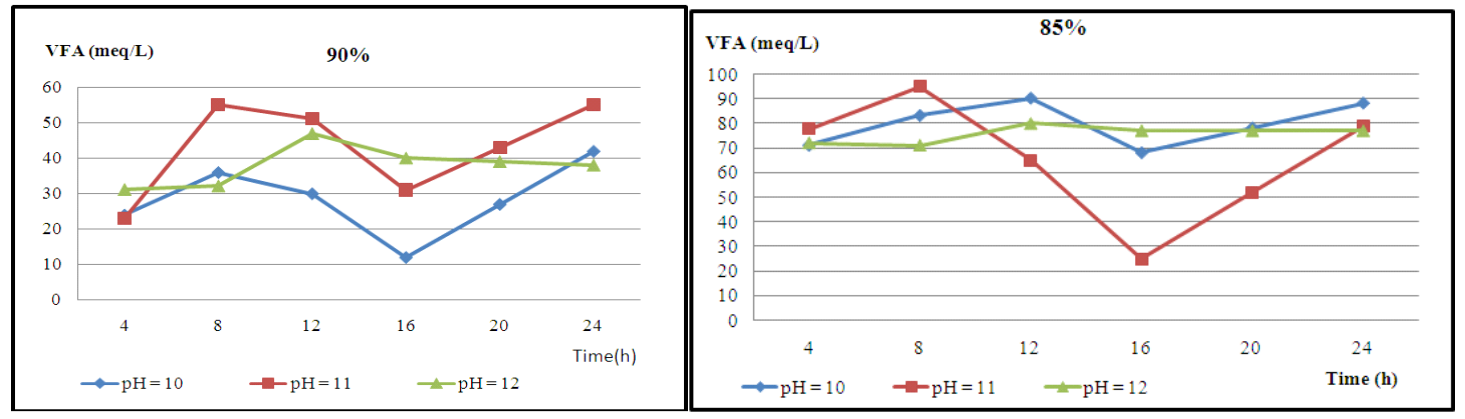

Fig.4: VFA changes by different $\mathrm{pH}$ of 10, 11, 12

On the contrary, alkalinity increased during the hyrolysis time from 4 to 16 hours at all moisture levels, then reduced steadly from 16 to
24 hours. The higher $\mathrm{pH}$ is, the higher alkalinity is. The peak of alkalinity reached 12000 $\mathrm{mgCaCO}_{3} / \mathrm{L}$ at $\mathrm{pH}$ of 12 after 24 hours.

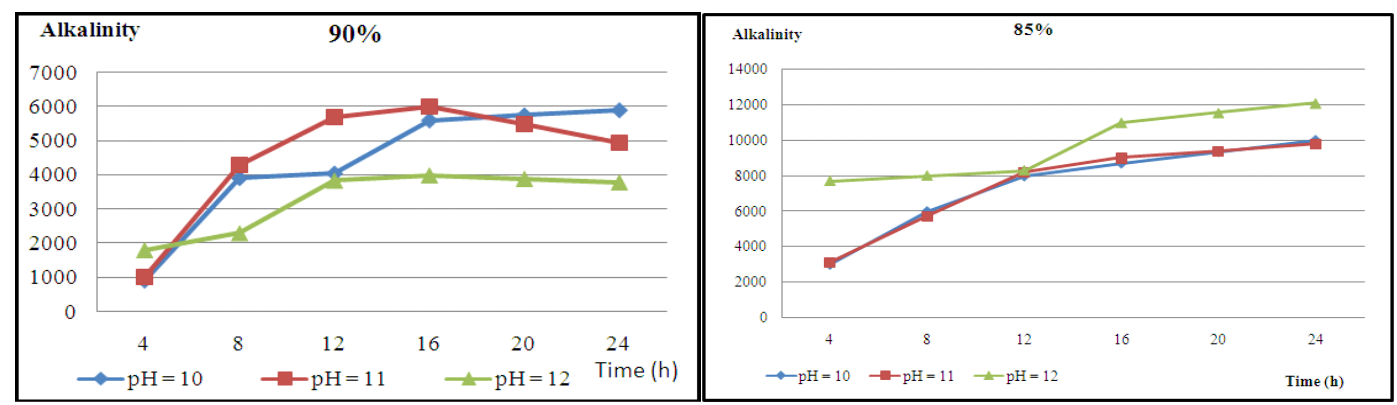

Fig.5: Alkalinity changes by different $\mathrm{pH}$ of $10,11,12$

The alkalinity increase can be explained by hydrolysis reaction of organic compound, releasing $\mathrm{HCO}_{3}{ }^{-}$and $\mathrm{NH}_{3}$. According to Ripley (1986), alkalinity changes depend on transform ability substrate to $\mathrm{HCO}_{3}{ }^{-}$(specified alkalinity) and VFA (indirect alkalinity). Total alkalinity is the sum of two above alkalinities. Therefore, VFA/alkalinity ratio is the most important parameter to evaluate organic components digestion process in the model.

At the beginning of the process, solubilization and hydrolysis were dominated cause to increase of alkalinity. After 12 hours, dissolved subtrate rate reduced, acidification reaction was dominated lead to decrease of alkalinity.

In generally, optimal condition for sludge digestion process was $\mathrm{pH}$ of 12, sCOD of 3600 $\mathrm{mg} / \mathrm{L}$ after 12 hour operation at room temperature. At $\mathrm{pH}$ of 12, after 20 digestion days, COD removal efficiency reached $62 \%$. Methane productivity when alkali/ $\mathrm{NaOH}$ was employed as a pretreatment was 4.9 times higher than sample without hydrolysis.

\subsection{Thermal pretreatment method}

$\mathrm{pH}$ of sludge samples decreased with reaction time; the higher temperature is, the faster $\mathrm{pH}$

\section{Trang 88}


decreases. After 2 hours, pH reduced $1.1-1.96$ unit at temperature of $55^{\circ} \mathrm{C}$ and decreased $3.6-$ 3.66 unit at temperature of $170^{\circ} \mathrm{C}$. This indicated that at high temperature, organic compounds dissolved more easily, especially long-chain fatty acids. VFA and intermediary acids cause to the amount of consumed $\mathrm{OH}^{-}$was high, then lead to decrease $\mathrm{pH}$ after 2 hours. As a result, alkalinity was increased; the faster $\mathrm{pH}$ reduces, the more alkalinity increases since hydrolysis process and acidification were occurred to form $\mathrm{HCO}_{3}{ }^{-}$and $\mathrm{NH}_{3}$.
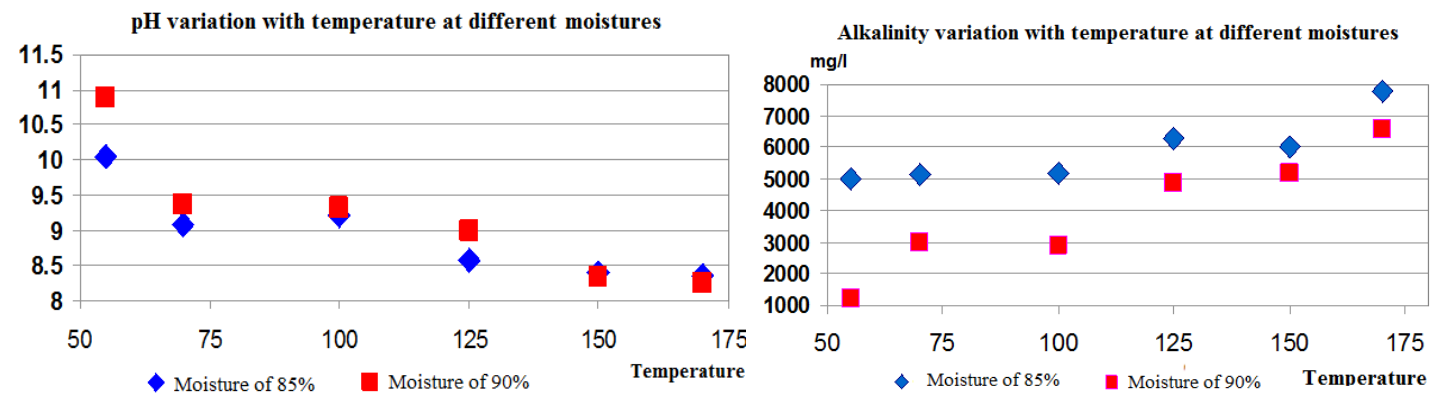

Fig.6: Effect of temperature to $\mathrm{pH}$ and alkalinity
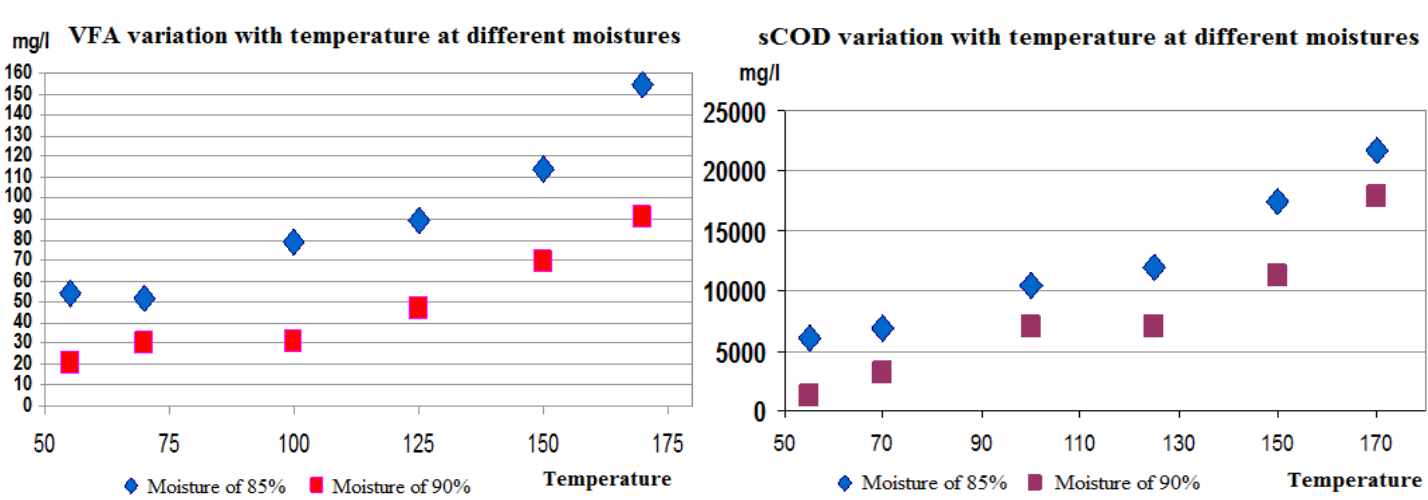

Fig.7: Effect of temperature to sCOD, VFA of sludge decomposition process

When temperature increased, the reaction occurred as quickly as, solubility COD, along with alkalinity and VFA content increased, shortened the sludge retention time, accelerated decomposition of sludge, created favorable conditions for the production of biogas in the next stage.
The higher the temperature is, the greater solubility is. Concentration of sCOD in effluent sludge sample increased with increasing temperature. At humidity of $85 \%$, temperature of $170^{\circ} \mathrm{C}$, the sCOD content peaked at $21,644 \mathrm{mg} / \mathrm{L}$. According to research by Vlyssides and Karlis (2004) in the hydrolysis at a temperature of about $50-90^{\circ} \mathrm{C}, \mathrm{pH}$ of 11 with reaction times from 1 to 10 hours, sCOD content increased after an hour treatment.

Concentration of VFA in temperature of $170^{\circ} \mathrm{C}$ was 3 times higher than the amount of VFA produced at $55^{\circ} \mathrm{C}$, it is easily to recognize that temperature was important impact on the process of anaerobic sludge decomposition in the bioreactor. At high temperature $\left(170^{\circ} \mathrm{C}\right)$, solubility COD of sludge increased and the 
amount of volatile fatty acids also increased. With high humidity, the produced VFA decreased (VFA at humidity of $90 \%$ was less than at humidity of $85 \%$ ). The ratio of VFA/alkalinity of the system was in the range of $0.01-0.02$; these values were lower than 0.4 , in accordance with the requirements of the stability conditions for the sludge decomposition process according to R. Roberts et al. after 2 hours of reaction.

3.3. Research and evaluation of results of the batch anaerobic digestion process

Operating mode without probiotics
Initial loading was $1.6 \mathrm{kgVS} / \mathrm{m}^{3} /$ day then gradually increased to $8 \mathrm{kgVS} / \mathrm{m}^{3} / \mathrm{day}$, with hydraulic retention time changes of $30,20,10,6$ days.

Research results showed that COD and VS removal efficiencies at loading of 1.6 $\mathrm{kgVS} / \mathrm{m}^{3} /$ day were the highest values, indicating long sludge retention time had the effect of increasing treatment efficiency. Meanwhile, the slow growth of bacteria were involved in substrate processing treatment, helped process more thoroughly.

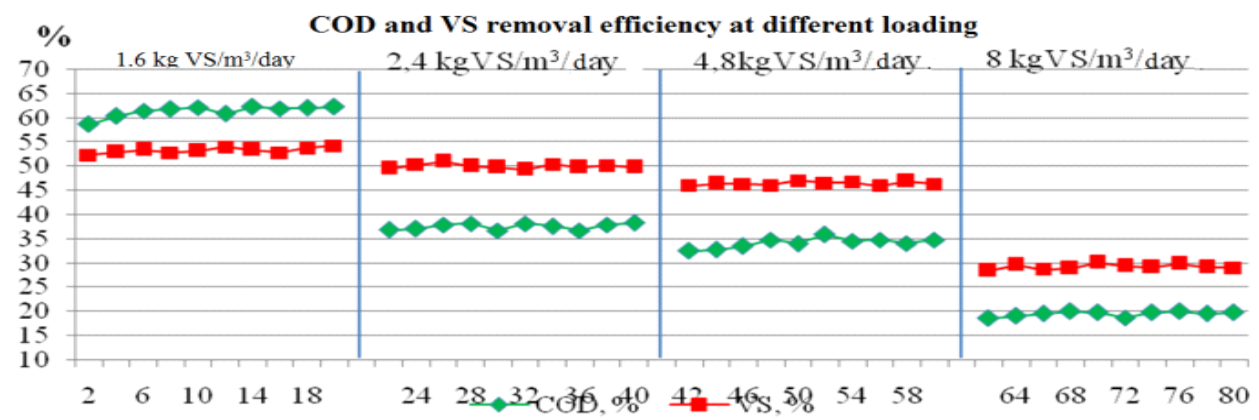

Fig.8: COD and VS removal efficiency at different loading

Production of biogas ranged from 0.523 to $2.36 \mathrm{~m}^{3} \mathrm{CH}_{4} / \mathrm{m}^{3}$.day. When the operation loading increased, the production of biogas also increased. This means that the treated amount of organic matter increased. However, the amount of produced $\mathrm{CH}_{4}$ per unit volatile solids mass decreased as the loading increased.

Table 2: Production of biogas variation with loadings

\begin{tabular}{|c|c|c|}
\hline Loading & $\mathrm{m}^{3} \mathrm{CH}_{4} / \mathrm{m}^{3}$ day & $\mathrm{LCH}_{4} / \mathrm{kgVS}$ \\
\hline $1.6 \mathrm{kgVS} / \mathrm{m}^{3} /$ day & $0.523-0.628$ & $343-402$ \\
\hline $2.4 \mathrm{kgVs} / \mathrm{m}^{3} /$ day & $0.9-0.96$ & $344-400$ \\
\hline $4.8 \mathrm{kgVS} / \mathrm{m}^{3} /$ day & $1.27-1.36$ & $318-330$ \\
\hline $8 \mathrm{kgVS} / \mathrm{m}^{3} /$ day & $1.98-2.36$ & $219-231$ \\
\hline
\end{tabular}

Thus, at the loading of $1.6-2.4 \mathrm{kgVS} / \mathrm{m}^{3} /$ day, generated the biogas was rather high (about 343 $402 \mathrm{LCH}_{4} / \mathrm{kgVS}$ ) compared to the remaining loadings.
Produced biogas is inversely proportional to the sludge retention time. This result is consistent with studies of Kiyohara et.al. in the sludge treatment from urban sludge treatment plant. In 
fact, microorganisms in the anaerobic sludge treatment process used organic matter to convert and did not occur overload or loss of sludge from the system.

The figure 10 showed the relationship between production of biogas and VFA with loadings. Production of biogas depends on the loading or in other words, depends on the sludge retention time.

Research results showed that loading of 1.6 $\mathrm{kgVS} / \mathrm{m}^{3} /$ day can reach the highest COD and VS removal efficiency compared to the remaining loading. Therefore, the loading of 1.6 $\mathrm{kgVS} / \mathrm{m}^{3} /$ day is optimal loading with sludge retention time of 30 days.

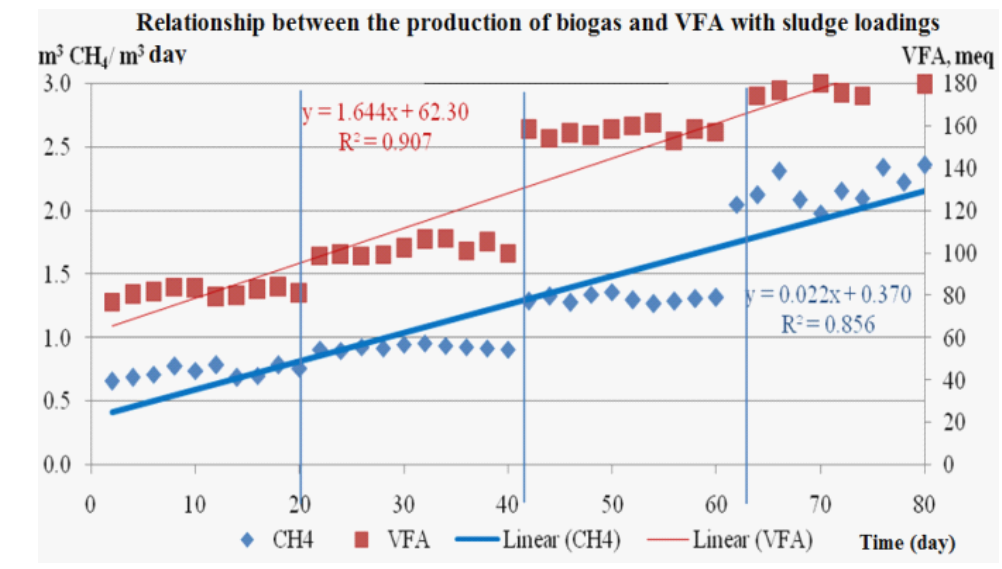

Fig.9: Relationship between the biogas production and VFA with sludge loadings

\section{Operating mode with probiotics}

The loading of $1.6 \mathrm{kgVS} / \mathrm{m}^{3} /$ day was chosen for the research in the direction of adding probiotics of AquaClean/ACF 32 in order to assess the catalytic efficiency to sludge treatment. Amount of microbial preparations in a dose of $10 \mathrm{ppm}$.

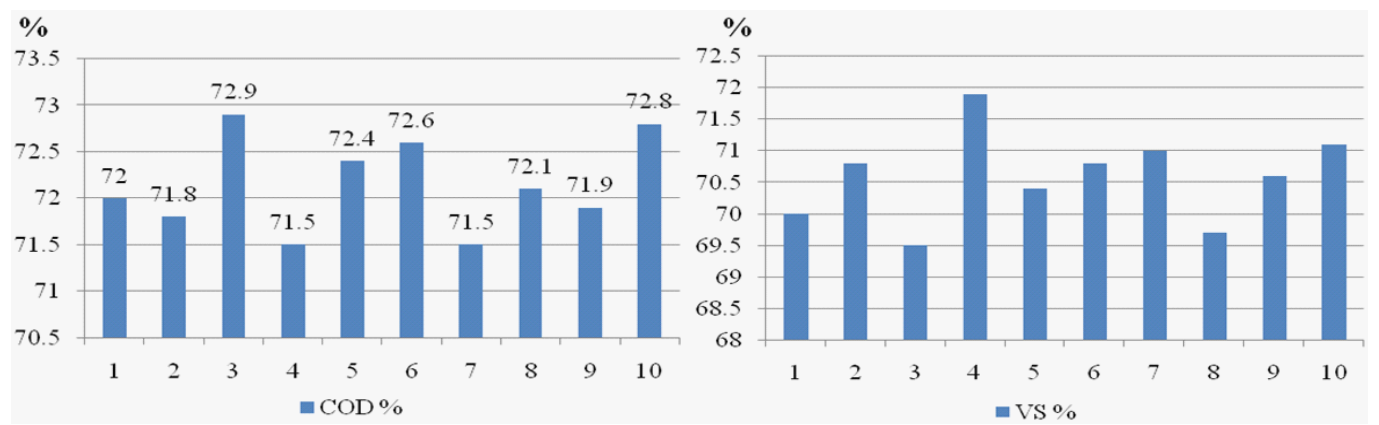



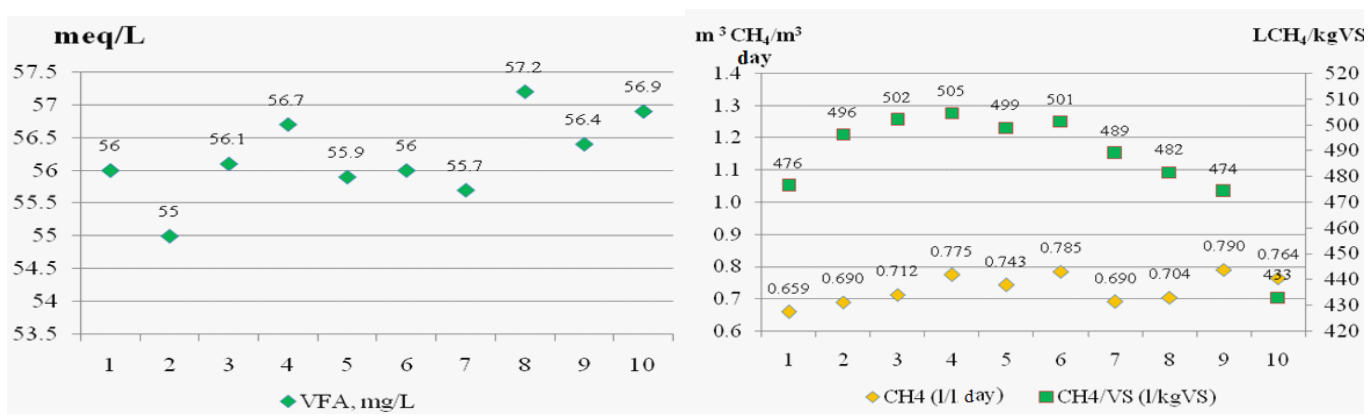

Fig.10: COD, VS, VFA removal efficiency and the biogas production with AquaClean/ACF 32

COD removal efficiency with adding preparations ranged from 71.5 to $72.9 \%$, an increase of $10.66 \%$ compared to without adding preparations.

Protein and carbohydrates are two main components that form to COD in sludge. Additional microbial preparations makes quantity and activity of microorganisms increase. The addition of microbial products promote metabolic process, increase efficient decomposition of organic matter in the sludge. Microbial preparations to help metabolize proteins into polypeptides, dipeptit, amino acids ... The amino acid further converted to ammonia, $\mathrm{CO}_{2}$ and organic acids with a less molecular weight.

Meanwhile, the carbohydrates are hydrolyzed polysaccharide, even metabolized to sugars ( $\mathrm{Ji}$ and Brune, 2005). Thus, the rate of hydrolysis, acetogens and methanogens increase. Amount of production biogas was higher, more stable process.

Thus, adding microbial preparations was positive effects to organic digestion process and increased biogas production in the system.

Table 3: Comparison of treatment efficiencies and biogas production in two operation modes

\begin{tabular}{|c|c|c|}
\hline Parameters & Without adding AquaClean/ACF 32 & With adding AquaClean/ACF 32 \\
\hline COD removal efficiency, \% & $61.37-62.48$ & $71.5-72.9$ \\
\hline VS removal efficiency, \% & $52.33-54.26$ & $69.5-71.9$ \\
\hline $\mathrm{m}^{3} \mathrm{CH}_{4} / \mathrm{m}^{3} /$ day & $0.523-0.628$ & $0.66-0.79$ \\
\hline $\mathrm{LCH}_{4} / \mathrm{kgVS}$ & $343-402$ & $433-505$ \\
\hline
\end{tabular}

Similarity to COD removal efficiency, VS removal efficiency and biogas production also increased $17 \%, 20-34 \%$ with adding microbial preparations, respectively, compared to without adding microbial preparations. VFA in the bioreactor with using microbial preparations was lower than without additional preparations. Effluent VFA was low, ranging from 55 to 57.2 $\mathrm{mg} / \mathrm{L}$. The rate of VFA/alkalinity was in the range of $0.007-0.008$, consistent with the process of anaerobic digestion. This ratio was used to observe the stability of the process. When the process is not stable, the concentration of VFA increased, alkalinity reduced leads to increase this rate.

\section{CONCLUSIONS}

Research and evaluation ofthe sludge hydrolysis process by alkaline pretreatment and thermal pretreatment methods showed that the optimal condition of sludge hydrolysis was $\mathrm{pH}$ of 12 (sCODof $3600 \mathrm{mg} / \mathrm{l}$ ), after 12 hours at room temperature. After 20 days of decomposition, at

\section{Trang 92}


$\mathrm{pH}$ of 12 , the amount of methane generated 4.9 times higher than methane production in sludge samples without alkaline pretreatment. VS removal efficiency was over $40 \%$ and COD removal efficiency reached $62 \%$.Besides, study the influence of temperature on the sludge decomposition process at temperature of $55^{\circ} ; 70^{\circ}$, $100^{\circ} ; 125^{\circ} ; 150^{\circ}$ and $170^{\circ} \mathrm{C}$ with two sludge samples with $85 \%$ and $90 \%$ humidity indicated that the higher temperature, the greater solubility of organic matter, content of sCOD, VFA, alkalinity in the effluent sludge sample increased with increasing temperature. As temperature increases, the reaction takes place as quickly, shortens decomposed time.Moreover, the research results indicated that ASBR model was appropriate for industrial sludge treatment by anaerobic digestion process, oriented simple and effective can be apply in Vietnamese conditions. At once, a combination of anaerobic biological and bioproducts to increase treatment efficiency of organic matter can be also used.

In case of using biological products, after 10 days of anaerobic digestion, COD and VS removal efficiency ranged from $61.92 \% \pm 1 \%$ $52.33 \% \pm 0.05 \%$, respectively; Production of methane was $372 \pm 58 \quad \mathrm{LCH}_{4} / \mathrm{kgVS}$ (corresponding to $0.5760 .1 \mathrm{~m}^{3} \mathrm{CH}_{4} / \mathrm{kg}$ sludge). In case of using biological products, after 10 days of anaerobic digestion, COD and VS removal efficiency were $71.8 \pm 1 \%$ and $70.7 \pm 1.2 \%$, respectively. COD removal efficiency increased by $10.66 \%$ and VS removal efficiency increased by $17 \%$ compared to without preparation. Production of methane ranged from 0.659 to 0.79 $\mathrm{m}^{3} \mathrm{CH}_{4} / \mathrm{kg}$ sludge.

\section{Nâng cao hiệu quả thu hồi khí sinh học từ bùn thải công nghiệp}

- Nguyễn Thị Thanh Phượng

Trường Đại học Bách khoa, ĐHQG-HCM

- Nguyễn Văn Phước

Viện Môi trường và Tài nguyên, ĐHQG-HCM

\section{TÓM TÁT:}

Bùn thải công nghiệp đang được quan tâm của xã hội và chính quyền các cấp. Đây là loại nguồn thải có khả năng gây ô nhiễm nước ngầm, nước mặt, không khí, thâm nhập vào chuỗi thực phẩm, gia tăng bệnh tật và gây ảnh hưởng nghiêm trọng đến sức khỏe con người nếu không được thu gom và xử lý hiệu quả. Do đặc điểm là bùn thải công nghiệp chứa thành phần hữu cơ cao nên công nghệ xử lý theo thương pháp sinh học kị khí, thu hồi khí sinh học cung cấp năng lượng phục vu cho nhu cầu cuộc sống được đánh giá là giải pháp ưu tiên và hữu hiệu.

Nội dung của nghiên cứu bao gồm thủy phân bùn ở giai đoạn tiền xử lý, sau đó phân hủy dịch thủy phân trong môi trường $k i$ 
khí tại mô hình kị khí dạng mẻ (ASBR) để khảo sát khả năng nâng cao hiệu quả thu hồi khí sinh học. Kết quả nghiên cứu trong điều kiện PTN đã xác định hiệu quả xử lý COD đạt đến $60 \%$, hàm lượng khí metan tăng 4,9 lần $(360 \mathrm{ml} / \mathrm{l})$ so với các nghiên cứu trước đây (không thủy phân trước khi phân hủy kị khí), $p H$ thủy phân 12, thời gian thủy phân 12 giờ và thời gian phân hủy kị khí sau 20 ngày ở nhiệt độ phòng (30-35oC). Kết quả phân hủy bùn sau 20 ngày ở tải trọng 1,6 kg VS/m3.ngày cho thấy hiệu quả loại bỏ $C O D$, VS lần lượt là 61.59 - 62.24, 52.33 $54.26 \%$. Lượng khí metan thu hồi khoảng $0.343-0.402 \mathrm{~m} 3 \mathrm{CH} 4 / \mathrm{kgVS}$ (tương ứng vớ $0.523-0.628 \mathrm{~m} 3 \mathrm{CH} 4 / \mathrm{kg}$ bùn).

Từ khóa: Bể phân hủy kị khí, quá trình thủy phân, nâng cao thu hồi khí sinh học, hàm lượng metan.

\section{REFERENCES}

[1]. APHA, AWWA, WEF, Standard Methods, 19th ed. Washington, DC, USA, (2005).

[2]. Chulhwan Park et al., Upgrading of Anaerobic Digestion by Incorporating two different hydrolysis processes. Journal of Bioscience and Bioengineering Vol 100, No.2, 164-167. (2005)

[3]. Datta R, Acidogenic fermentation of lignocellulose - acid yield and conversion of components. Biotechnol. Bioeng. 23: 2167-2170, (1981).

[4]. Haug, T.R., Stuckey, D.C., Gossett, J.M., McCarty, P.L., Effect of thermal pretreatment on digestibility and dewaterability of organic sludges. J. Water Pollut. Control. Fed. 50, 73-85, (1978.).

[5]. Hiraoka, M., Highly efficient anaerobic digestion with thermal pretreatment. Water Sci. Technol. 17, 529, (1984).

[6]. Ji, R., Brune, A., Digestion of peptidic residues in humic substances by an alkalistable and humic-acid-tolerant proteolytic activity in the gut of soilfeeding termites. Soil Biol. Biochem. 37 (9), 1648-1655, (2005).

[7]. Kiyohara, Y., Li, Y., Miyahara, T., Mizuno, O. and Noike, T. Treatment characteristics of high strength sewage sludge by thermophilic anaerobic digestion. Proceedings JSCE. No. 601/VII-8, 35-43 (in Japanese), (1998).

[8]. Li, Y.Y., Noike, T., Upgrading of anaerobic digestion of waste activated sludge by thermal pretreatment. Water Sci. Technol. 26, 857-866, (1992).

[9]. Lin J. G., Cahn C. N. and Chang S. C., Enhancement of anaerobic digestion of waste activated sludge by alkaline solubilization. Bioresource Technology

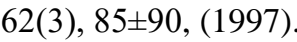

[10]. Liu X.L., Liu H., Chen J.H., Du G., Chen J. Enhancement of solubilization and acidification of waste activated sludge by pretreatment. Waste Management. 28 (12), 2614-2622, (2008).

[11]. Mukherjee, R.S., Levine, A.D., Chemical solubilization of particulate organics as a pretreatment approach. Water. Sci.Technol. 26, 2289-2292, (1992).

[12]. Novelli, A., Ottonello, F., Converti, A., et al., Alkaline hydrolysis for the treatment of the organic fraction of municipal solid wastes and sludges. Chem. Biochem. Eng. Quart. 9, 195, (1995). 